\title{
Contrasting two- and three-dimensional crystal properties of isomeric dialkyl phthalates
}

\author{
Katherine E. Plass, Keary M. Engle, and Adam J. Matzger* \\ Department of Chemistry and the Macromolecular Science and Engineering Program, University of \\ Michigan, 930 N. University, Ann Arbor, MI 48109-1055 \\ matzger@umich.edu
}

\section{Supporting Information}

(1) Synthesis and characterization of compounds

(2) Experimental details

(3) STM image of the two-dimensional crystal of 18-para in phase II

(4) Table of the solution ratios examined by STM and the identity of the resulting monolayers

(5) STM images of 1:1 meta:para solution mixtures

(6) Melting points of various alkyl phthalate esters

(7) Table of the bulk properties of the less stable polymorph of 17-meta

(8) DSC curves of 17-meta polymorphs

(9) DSC curves of all reported compounds 
(1) Synthesis and characterization of compounds

All solvents were purchased from Fisher Scientific. All reagents were used as received and were purchased from Acros Organics except 1-octadecanol (Sigma Chemical Co.). Column chromatography was carried out on silica gel (0.040-0.063 mm particle size, EM Sciences).

General preparation of dialkyl isophthalates: To a solution of the appropriate 1-alcohol (3.110 mmol) dissolved in degassed anhydrous $\mathrm{CH}_{2} \mathrm{Cl}_{2}(20 \mathrm{~mL})$, triethylamine $(0.108 \mathrm{~mL})$, and 4dimethylaminopyridine $(35.1 \mathrm{mg}, 0.287 \mathrm{mmol})$ was added the appropriate phthaloyl dichloride (157.9 $\mathrm{mg}, 0.777 \mathrm{mmol})$. The solution was heated to reflux under a nitrogen atmosphere for several days. The solvent was removed by rotary evaporation. The resulting solid was dissolved in $\mathrm{CH}_{2} \mathrm{Cl}_{2}(50 \mathrm{~mL})$ and washed with saturated $\mathrm{NaHCO}_{3}(25 \mathrm{~mL})$ and brine $(25 \mathrm{~mL})$. Pure product was obtained by recrystallization from methyl ethyl ketone (17-para and 18-para) or column chromatography with 5\% ethyl acetate in hexanes (17-ortho).

Preparation of diheptadecyl phthalate (17-ortho). Yield: $218.6 \mathrm{mg}(44.8 \%) . \mathrm{mp} 51.48{ }^{\circ} \mathrm{C}$ (the peak of the melting endotherm measured by differential scanning calorimetry at $10{ }^{\circ} \mathrm{C} / \mathrm{min}$ ). IR: 2956 (s), 2918 (vs), 2877 (m), 1720 (s), 1456 (vw), 1296 (m), 1254 (vw), 723 (vw) cm-1. ${ }^{1} \mathrm{H}$ NMR (400 MHz, $\mathrm{CDCl}_{3}$,

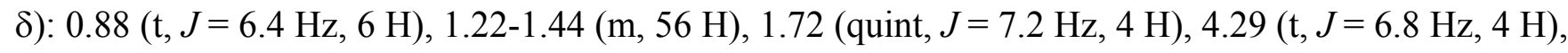
$7.53\left(\mathrm{XX}^{\prime}\right.$ in an $\mathrm{AA}^{\prime} \mathrm{XX}$ ' spin system, $\left.2 \mathrm{H}\right), 7.71$ (AA' in an $\mathrm{AA}^{\prime} \mathrm{XX}$ ' spin system, $\left.2 \mathrm{H}\right) .{ }^{13} \mathrm{C}$ NMR (100 $\mathrm{MHz}, \mathrm{CDCl}_{3}, \delta$ ): 14.06, 22.67, 26.00, 28.60, 29.31, 29.35, 29.54, 29.60, 29.65, 29.70 (broad), 31.93, 65.84, 128.84, 130.82, 132.44, 167.61. Anal. Calcd for $\mathrm{C}_{42} \mathrm{H}_{74} \mathrm{O}_{4}$ : C 78.45, H 11.60; Found: C 78.61, $\mathrm{H}$ 11.46. $\mathrm{MS}\left(\mathrm{CI}, \mathrm{CH}_{4}\right): m / z 643.7\left[\mathrm{MH}^{+}\right]$.

Preparation of diheptadecyl terephthalate (17-para). Yield: $416.6 \mathrm{mg}(83.8 \%) . \mathrm{mp} 77.52{ }^{\circ} \mathrm{C}$ (the peak of the melting endotherm measured by differential scanning calorimetry at $10{ }^{\circ} \mathrm{C} / \mathrm{min}$ ). IR: 2962 (m), 2916 (vs), 2850 (vs), 1718 (s), 1471 (w), 1288 (w), 1280 (m), 725 (vw) cm ${ }^{-1}$. ${ }^{1} \mathrm{H}$ NMR (400 MHz, $\left.\mathrm{CDCl}_{3}, \delta\right): 0.88(\mathrm{t}, J=6.8 \mathrm{~Hz}, 6 \mathrm{H}), 1.20-1.48(\mathrm{~m}, 56 \mathrm{H}), 1.79$ (quint, $\left.J=7.2 \mathrm{~Hz}, 4 \mathrm{H}\right), 4.33(\mathrm{t}, J=6.8$ 
$\mathrm{Hz}, 4 \mathrm{H}), 8.10$ (s, $4 \mathrm{H}) .{ }^{13} \mathrm{C} \mathrm{NMR}\left(100 \mathrm{MHz}, \mathrm{CDCl}_{3}, \delta\right): 14.11,22.68,26.01,28.65,29.27,29.36,29.52$, 29.58, 29.69 (broad), 31.92, 65.55, 129.44, 134.16, 165.85. Anal. Calcd for $\mathrm{C}_{42} \mathrm{H}_{74} \mathrm{O}_{4}$ : C 78.45, $\mathrm{H}$ 11.60; Found: C 78.74, H 11.75. MS (CI, $\left.\mathrm{CH}_{4}\right): m / z 643.6\left[\mathrm{MH}^{+}\right]$.

Preparation of dioctadecyl terephthalate (18-para). Yield: $343.0 \mathrm{mg}(66.1 \%)$. mp $86.22{ }^{\circ} \mathrm{C}$ (the peak of the melting endotherm measured by differential scanning calorimetry at $10{ }^{\circ} \mathrm{C} / \mathrm{min}$ ). IR: 2955 (s), 2918 (vs), 2848 (s), 1721 (s), 1469 (s), 1299 (m), 1244 (m), 722 (m) cm ${ }^{-1} .{ }^{1} \mathrm{H}$ NMR (400 MHz, $\mathrm{CDCl}_{3}$,

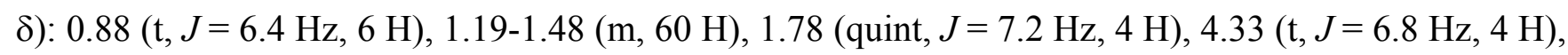
8.10 (s, $4 \mathrm{H}) .{ }^{13} \mathrm{C}$ NMR $\left(100 \mathrm{MHz}, \mathrm{CDCl}_{3}, \delta\right): 14.09,22.69,26.01,28.65,29.27,29.36,29.52,29.58$, 29.69 (broad), 31.92, 65.56, 129.45, 134.17, 165.87. Anal. Calcd for $\mathrm{C}_{42} \mathrm{H}_{74} \mathrm{O}_{4}$ : C 78.45, H 11.60; Found: C 78.44, H 11.81. MS (CI, $\left.\mathrm{CH}_{4}\right): m / z 671.7\left[\mathrm{MH}^{+}\right]$.

Diheptadecyl isophthalate (17-meta), dioctadecyl isophthalate (18-meta), and dioctadecyl phthalate (18-ortho) were synthesized as previously reported in Plass, K. E.; Kim, K.; Matzger, A. J. J. Am. Chem. Soc. 2004, 126, 9042-9053 and Plass, K. E.; Engle, K. M.; Cychosz, K. A.; Matzger, A. J. Nano Lett. 2006, 6, 1178-1183. 
(2) Experimental details

\section{Scanning tunneling microscopy}

A Nanoscope E STM (Digital Instruments) was used for all imaging. Highly oriented pyrolytic graphite (HOPG) (SPI-1 grade, Structure Probe Inc.) was used as a substrate for monolayer formation. A drop of solution in phenyloctane $(1 \mu \mathrm{L})$ was placed on freshly cleaved HOPG to obtain a selfassembled monolayer. Note that for competitive adsorption experiments, binary component solutions were prepared, then applied to the surface. The tips were made from Pt/Ir wire $(20 \%$ Ir, 0.010 inch diameter, California Fine Wire) by mechanical cutting and shaped in situ by applying short voltage pulses. The quality of the tips was verified by scanning the HOPG surface under the monolayer at reduced bias voltage. All images are unfiltered. STM imaging was performed under ambient conditions and typical STM settings include $300 \mathrm{pA}$ of current and $800 \mathrm{mV}$ of bias voltage (sample positive). Measured structural parameters for each compound are given in Table 1. Note that for a specific image, the cell constants may vary from average due to the drift of the STM tip. Cell constants and symmetries were determined by examining many images in both trace and retrace modes from different imaging sessions to account for this phenomenon.

\section{Computational modeling}

The packing structures apparent from the average measured metrics and symmetry of the STM images were modeled using Cerius ${ }^{2}$ version 4.2 (Accelrys Inc.). Energy minimization was performed using a COMPASS forcefield. The periodic three-dimensional models used in lattice energy calculations were minimized with a large $c$-axis, keeping out-of-plane parameters fixed. Non-periodic assemblies from these models were overlaid on a fixed graphite slab for cluster simulations, from which the computed unit cell parameters (Table 1) and models (Figures 2, 3, and 4) were obtained. The perturbation of the periodic structure upon simulation of adsorption to the graphite slab was minimal in all cases. 
(3) STM image of the two-dimensional crystal of 18-para in phase II

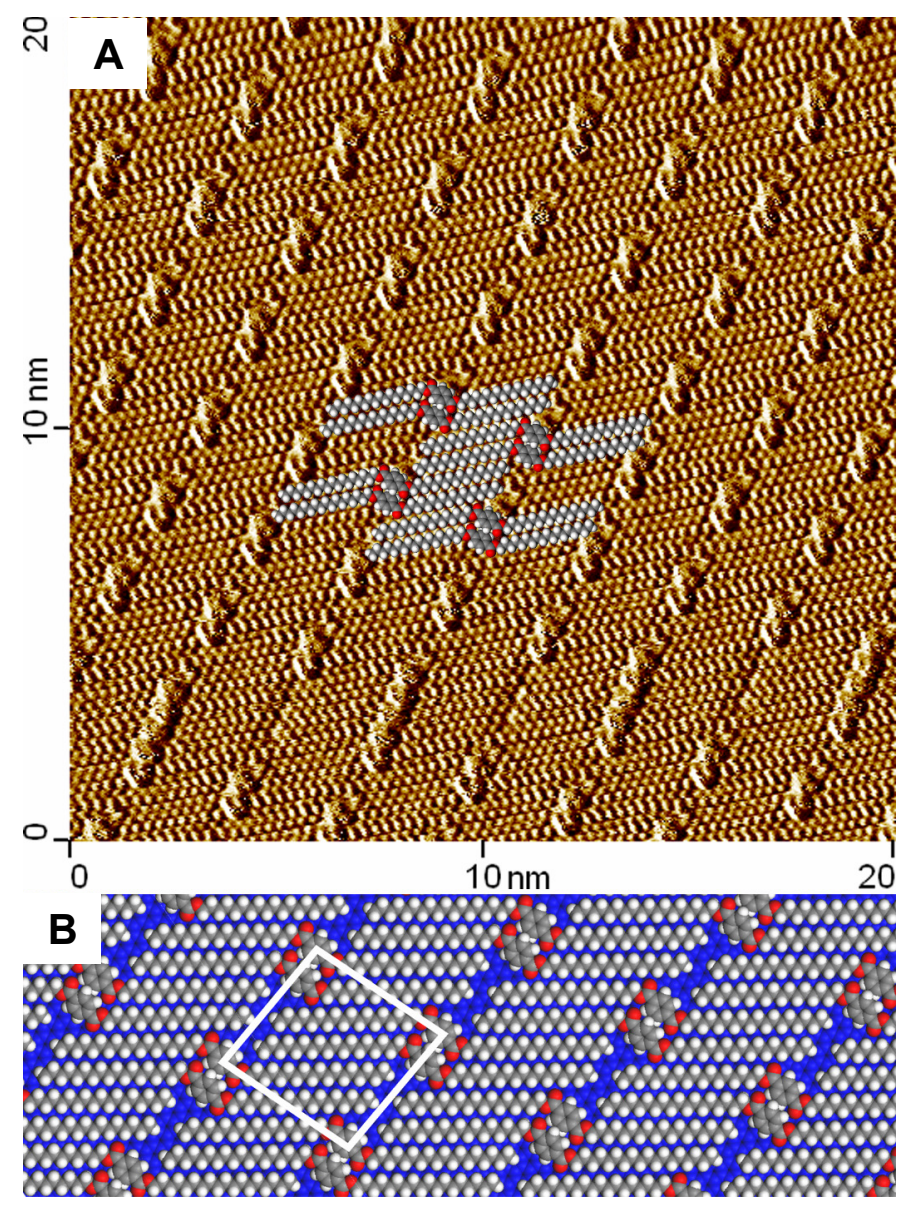

Figure S1. Two-dimensional crystal of 18-para in phase II. STM image with overlaid molecular models and computed packing pattern with unit cell of phase II of 18-para. Cell parameters: $Z^{\prime}=1.0$, plane group $=p 2$, experimental unit cell: $a(\mathrm{~nm})=2.4(2), b(\mathrm{~nm})=2.4(3), \alpha\left(^{\circ}\right)=89(2)$, computed unit cell: $a$ $(\mathrm{nm})=2.42, b(\mathrm{~nm})=2.34, \alpha\left(^{\circ}\right)=83.2$. 
(4) Table of the solution ratios examined by STM and the identity of the resulting monolayers

Table S1. The solution ratios of ortho:meta or ortho:para that were examined, and the two-dimensional crystal that formed on the surface, as well as the calculated free energy differences for each pair of isomers.

\begin{tabular}{|c|c|c|c|c|}
\hline \multirow[b]{2}{*}{ ratios: } & \multicolumn{4}{|c|}{ isomer pairs examined } \\
\hline & 17-ortho:17-meta & 17-ortho:17-para & 18-ortho:18-meta & 18-ortho:18-para \\
\hline $1: 1$ & 17-meta & 17-para & 18-meta & $\begin{array}{c}\text { 18-para phases I } \\
\text { and II }\end{array}$ \\
\hline $9: 1$ & 17-meta & 17-para & - & $\begin{array}{c}\text { 18-para phases I } \\
\text { and II }\end{array}$ \\
\hline $19: 1$ & 17-meta & - & 18-meta & - \\
\hline $24: 1$ & 17-meta & - & 18-meta & - \\
\hline $30: 1$ & - & 17-para & & $\begin{array}{c}\text { 18-para phases I } \\
\text { and II }\end{array}$ \\
\hline $49: 1$ & 17-meta & - & $\begin{array}{l}\text { 18-meta and } \\
\text { cocrystal }\end{array}$ & - \\
\hline $50: 1$ & & - & $\begin{array}{l}\text { 18-meta } \text { and } \\
\text { cocrystal }\end{array}$ & - \\
\hline $60: 1$ & 17-meta & 17-para & 18-ortho & 18-para phase I \\
\hline $80: 1$ & 17-ortho & 17-para & 18-ortho & 18-ortho \\
\hline 99:1 & - & 17-ortho & - & 18-ortho \\
\hline $\begin{array}{l}\text { largest ratio at which } \\
\text { only minority } \\
\text { component observed: }\end{array}$ & $1: 60$ & $1: 80$ & $1: 24$ & $1: 60$ \\
\hline $\begin{array}{c}\text { smallest ratio at } \\
\text { which only majority } \\
\text { component observed: }\end{array}$ & $1: 80$ & $1: 99$ & $1: 60$ & $1: 80$ \\
\hline $\begin{array}{l}\text { minimum kcal mol} \\
\text { difference: }\end{array}$ & 2.42 & 2.59 & 1.88 & 2.42 \\
\hline $\begin{array}{l}\text { maximum kcal mol} \\
\text { difference: }\end{array}$ & 2.59 & 2.72 & 2.42 & 2.59 \\
\hline average difference: & 2.51 & 2.66 & 2.15 & 2.51 \\
\hline range: & 0.17 & 0.13 & 0.54 & 0.17 \\
\hline
\end{tabular}


(5) STM images of 1:1 meta:para solution mixtures

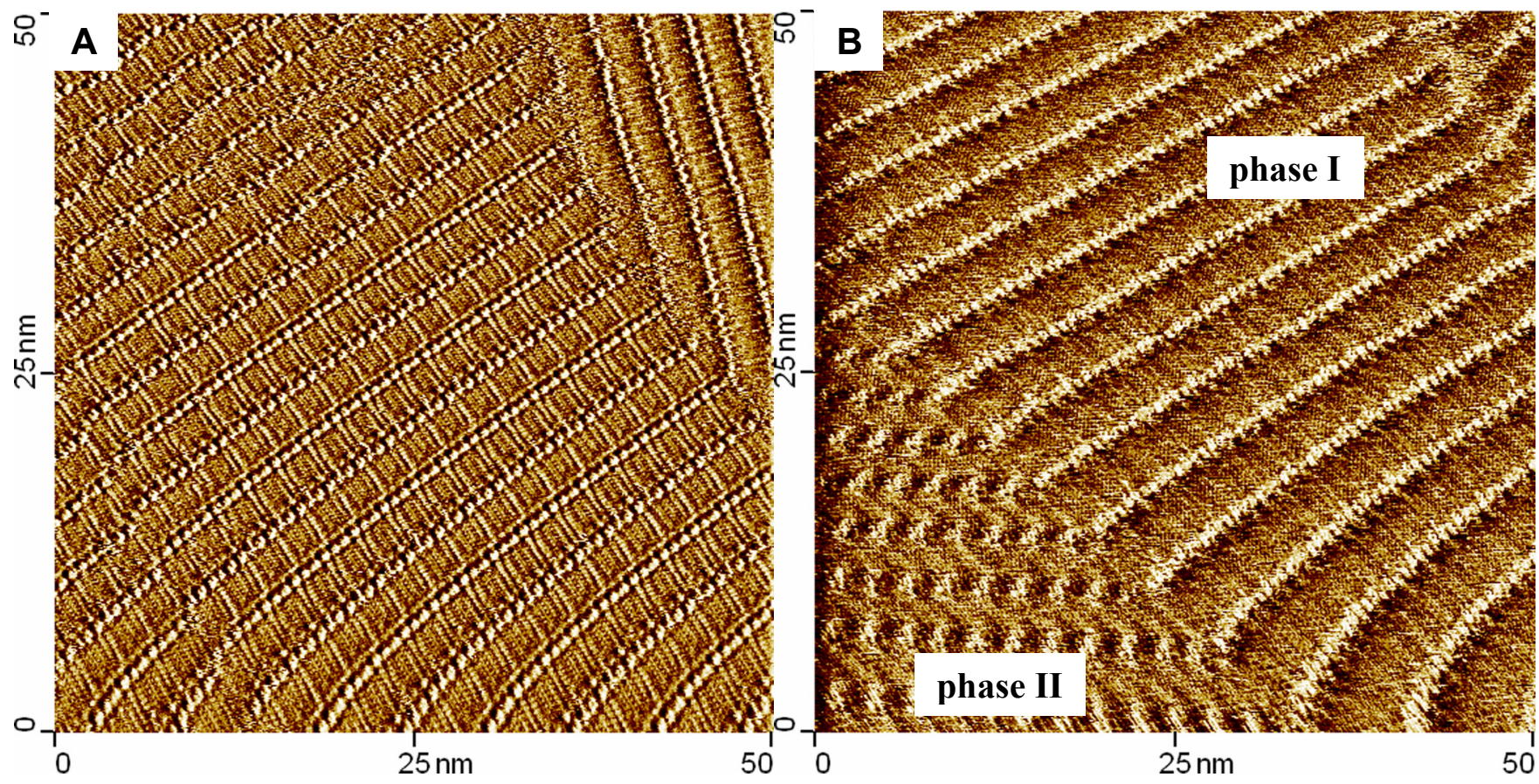

Figure S2. STM images of two-dimensional crystals formed from 1:1 solutions of meta and para esters, showing that the para isomers adsorb preferentially. A) Monolayer formed from a mixture of 17-meta and 17-para, where 17-para adsorbs to the surface, which is apparent from the contrast difference between the adjacent columns of benzene rings $(300 \mathrm{pA}, 800 \mathrm{mV}, 10.2 \mathrm{~Hz})$. B) Monolayer formed from a mixture of 18-meta and 18-para, where 18-para, in both phases I and II, adsorbs to the surface (300 pA, $800 \mathrm{mV}, 10.2 \mathrm{~Hz}$. 
(6) Table S2. Melting points of various alkyl phthalate esters.

\begin{tabular}{ccccc}
\hline & & \multicolumn{2}{c}{ melting points $\left(^{\circ} \mathrm{C}\right)$} & \\
& order & ortho- & meta- & para- \\
\hline dimethyl phthalate & $o<m<p$ & $-0.8^{\mathrm{a}}$ & $67^{\mathrm{b}}$ & $141-142^{\mathrm{b}}$ \\
diethyl phthalate & $o<m<p$ & $-40.0^{\mathrm{a}}$ & $11.5^{\mathrm{b}}$ & $44^{\mathrm{b}}$ \\
ditertbutyl phthalate & $o<m<p$ & $73.5-74^{\mathrm{c}}$ & $80-82^{\mathrm{d}}$ & $118^{\mathrm{d}}$ \\
dioctyl phthalate & $o \sim m<p$ & -25.2 and $-33.5^{\mathrm{e}}$ & -26.8 and $-42.5^{\mathrm{e}}$ & $39-40^{\mathrm{a}}$
\end{tabular}

a. Matsuda, S.; Kikkawa, S. Tech. Rep. Osaka Univ. 1957, 7, 199-214.

b. Gur'yanova, E. N.; Grishko, N. I. J. Struc. Chem. 1963, 4, 339-342.

c. Weber, G.; Menke, K.; Hopf, H. Chem. Ber. 1980, 113, 531-541.

d. Buckle, D. R.; Smith, H. J. Chem. Soc. C. 1971, 2821-2823.

e. Onset temperature of the endothermic phase transitions measured by DSC when heating at a rate of $5.0{ }^{\circ} \mathrm{C} \mathrm{min}^{-1}$. 
(7) Table of the bulk properties of the less stable polymorph of 17-meta.

Table S3. Melting point, heat of melting $\left(\Delta \mathrm{H}_{\mathrm{m}}\right)$, and entropy of melting $\left(\Delta \mathrm{S}_{\mathrm{m}}\right)$ for the less stable polymorph of 17-meta.

\begin{tabular}{lcccc}
\hline & $\begin{array}{c}\text { onset } \\
\text { temperature of } \\
\text { the melting } \\
\text { curve }\left({ }^{\circ} \mathrm{C}\right)^{\mathrm{a}}\end{array}$ & $\begin{array}{c}\text { peak } \\
\text { temperature of } \\
\text { the melting } \\
\text { curve }\left({ }^{\circ} \mathrm{C}\right)^{\mathrm{a}}\end{array}$ & $\begin{array}{c}\Delta \mathrm{H}_{\mathrm{m}}(\mathrm{kcal} \\
\left.\mathrm{mol}^{-1}\right)\end{array}$ & $\begin{array}{c}\Delta \mathrm{S}_{\mathrm{m}}\left(\mathrm{kcal} \mathrm{mol}^{-1}\right. \\
\left.\mathrm{K}^{-1}\right)\end{array}$ \\
\hline $\mathbf{1 7 - m e t a}$ (form II) & 48.4 & 49.6 & 29.6 & 0.093
\end{tabular}

a. Measured by DSC at $10^{\circ} \mathrm{C} \min ^{-1}$ 
(8) DSC curves of 17-meta polymorphs

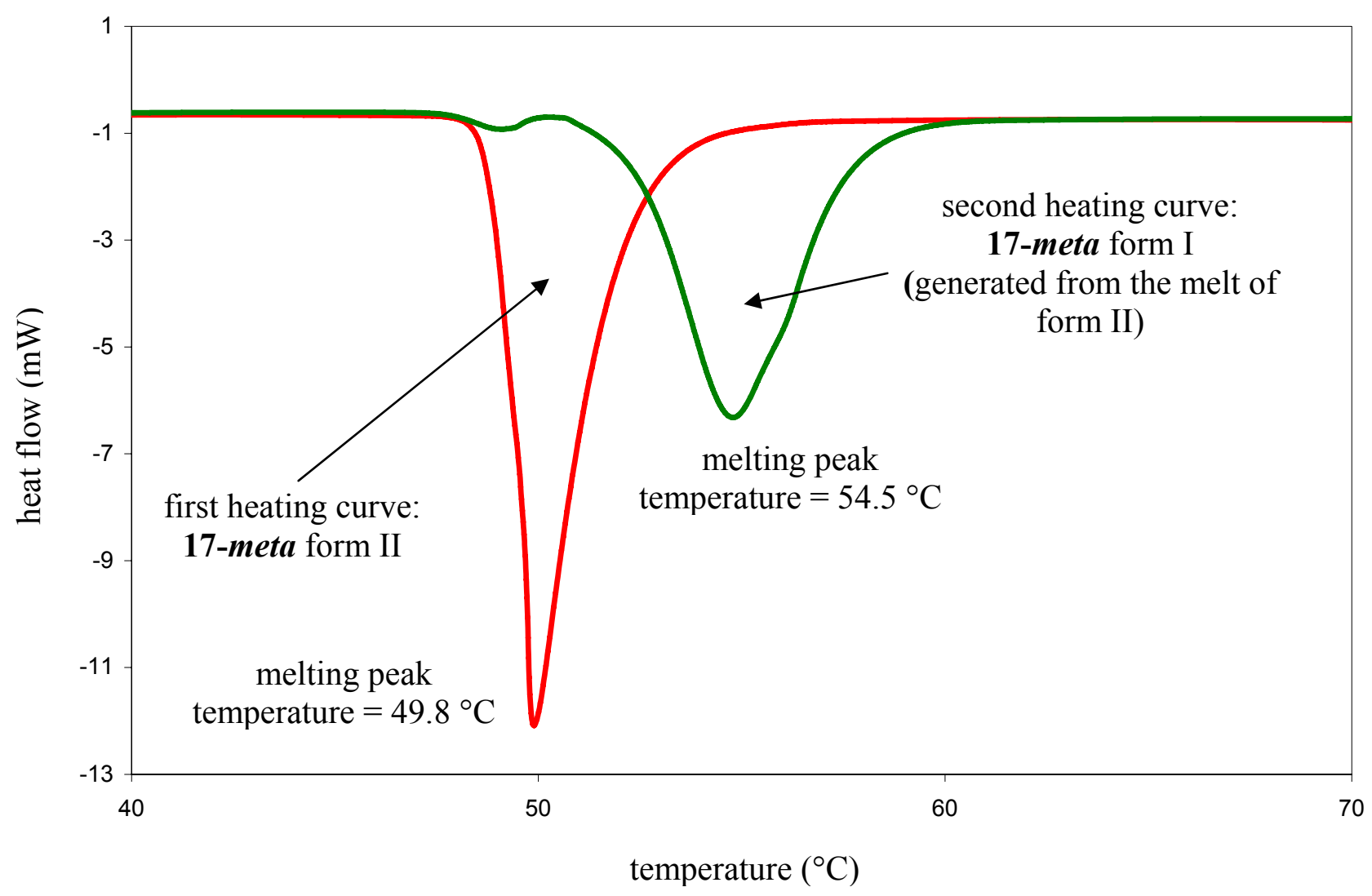

Figure S3. DSC curves of form II, which transforms to the more stable, higher melting form I upon cooling. 
(9) DSC curves of all reported compounds

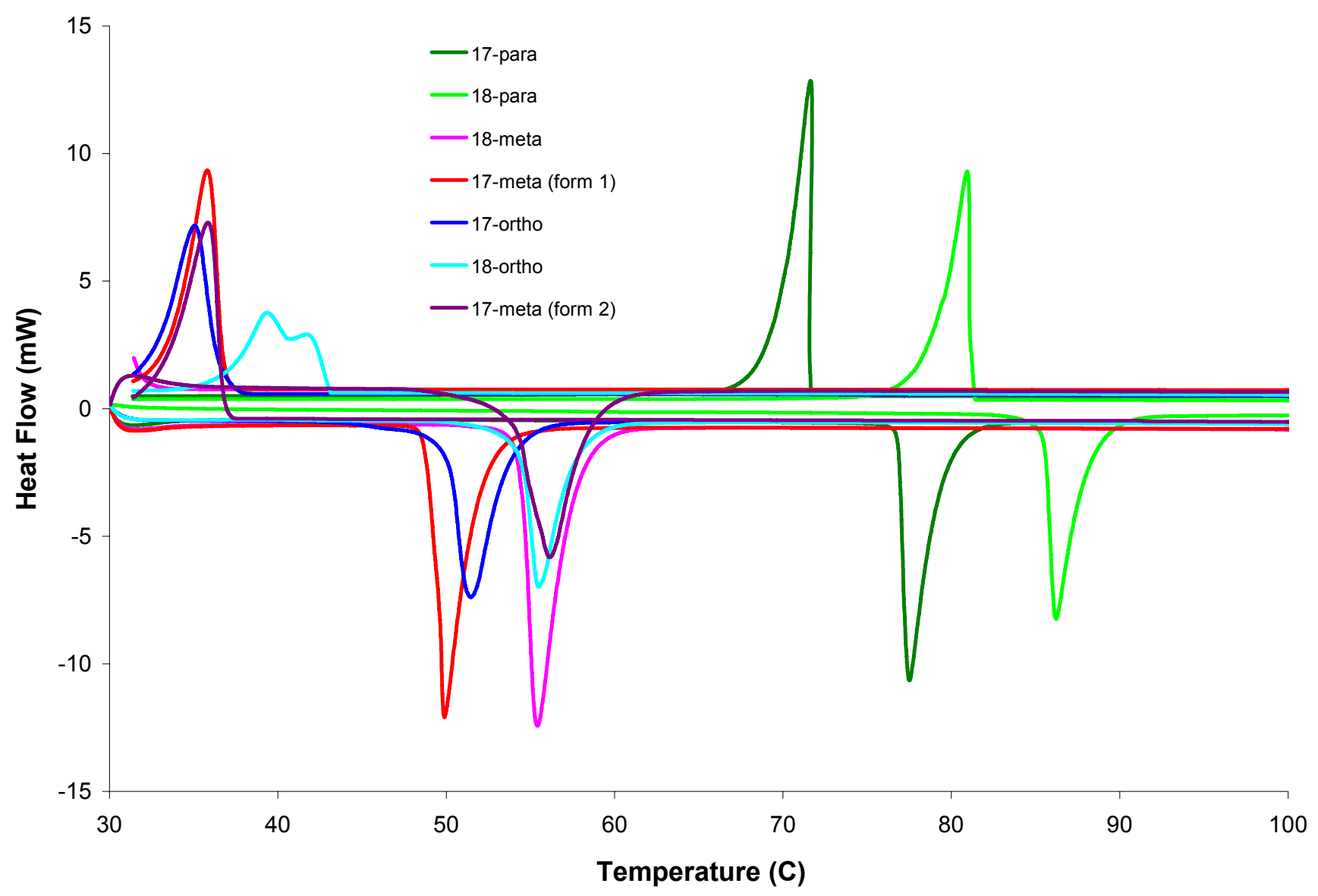

Figure S4. DSC curves of all odd and even isomers (scan rate of $10{ }^{\circ} \mathrm{C} \mathrm{min}^{-1}$ ). Note that the melting peak (pointing downwards) and the crystallization peak (pointing upwards) is comparable for most compounds. The exceptions are 18-ortho, which recrystallizes in two steps, and 18-meta, which crystallized off scale. 